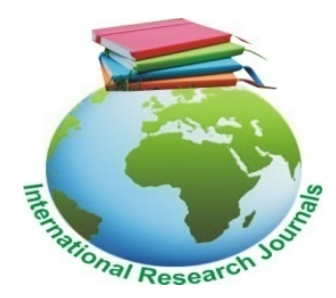

International Research Journal of Microbiology (IRJM) (ISSN: 2141-5463) Vol. 4(4) pp. 119-124, April, 2013

Available online http://www.interesjournals.org/IRJM

DOI: http:/dx.doi.org/10.14303/irjm.2012.093

Copyright @ 2013 International Research Journals

Full Length Research Paper

\title{
Enrichment of pig dung with selected crop wastes for the production of biogas
}

\author{
O.T. Okareh ${ }^{1 *}$, A.T.Adeolu ${ }^{1}$ and O.I. Shittu ${ }^{2}$ \\ ${ }^{1}$ Department of Environmental Health Sciences, Faculty of Public Health, University of Ibadan, Ibadan, Oyo State, \\ Nigeria \\ ${ }^{2}$ Department of Civil Engineering, Faculty of Technology, University of Ibadan, Ibadan, Oyo State, Nigeria \\ * Corresponding Author E-mail: dapsy2001@yahoo.co.uk
}

\begin{abstract}
Effect of pig dung enriched with selected crop wastes for the production of biogas was investigated. Bean husks, peels of yam, cassava and plantain were processed with fresh dung of pig in a combined ratio of 1:4 (crop wastes: pig dung); on wet weight basis. The mixture was digested for 16 days. Bacterial, fungal and yeast burden in the biogas ranged from $1.5 \times 10^{11} \mathrm{cfu} / \mathrm{ml}$ to $3.5 \times 10^{11} \mathrm{cfu} / \mathrm{ml}, 0.8 \mathrm{x}$ $10^{7} \mathrm{sfu} / \mathrm{ml}$ to $1.4 \times 10^{7} \mathrm{sfu} / \mathrm{ml}$ and $1.8 \times 10^{7} \mathrm{sfu} / \mathrm{ml}$ to $2.4 \times 10^{7} \mathrm{sfu} / \mathrm{ml}$ respectively. The $\mathrm{pH}$ of the digesting materials ranged from 5.2 to 7.1 in which the $\mathrm{pH}$ initially decreased and subsequently increased as the digestion progressed. Temperature range of $26^{\circ} \mathrm{C}-34^{\circ} \mathrm{C}$ was recorded during the digestion process. The gas yield ranged from $85.5 \mathrm{mmH}_{2} \mathrm{O}$ to $314.5 \mathrm{mmH}_{2} \mathrm{O}$. The chemical analysis of biogas evolved from the mixture of pig dung and selected crop wastes was $70.6 \%$ for $\mathrm{CH}_{4}, 13.2 \%$ for $\mathrm{NH}_{3}, 5.3 \%$ for $\mathrm{H}_{2} \mathrm{~S}, 4.7 \%$ for $\mathrm{CO}_{2}$ and trace of other unknown gases which were found to be low. It was observed that the quantity of the pig dung and the mixture of the selected crop wastes fed into the digester had significant effect on the biogas generated $(<0.05)$. Therefore, the utilization of pig dung and the selected crop wastes for the production of biogas is of dual benefits. It serves as waste reduction strategy to improve the environment while the residue from the digester has fertilizing value which can be used as soil conditioner.
\end{abstract}

Keywords: Pig dung, Crop wastes, Biogas, Digestion, Slurry.

\section{INTRODUCTION}

Production of methane-rich biogas through anaerobic digestion of organic materials provides a versatile carrier of renewable energy, as methane can be used in replacement for fossil fuels in both heat and power generation and as a vehicle fuel, thus contributing to cutting down the emissions of greenhouse gases and slowing down the climate change. Methane production through anaerobic digestion has been evaluated as one of the most energy-efficient and environmentally benign ways of producing vehicle biofuel (LBS, 2002).

Methane production from energy crops and crop residues could be an interesting option for increasing the domestic biofuel production (Amon et al., 2001). Biogas, also called digester gas, typically refers to methane produced by the fermentation of organic matter including manure, wastewater sludge, municipal solid waste, or any other biodegradable feedstock in anaerobic conditions. Biogas is the mixture of gas produced by microorganisms (methanogenic bacteria) while undergoing biodegradation of the organic materials in anaerobic conditions. Under strictly anaerobic conditions, solid wastes can be digested by microorganisms to generate combustible gas with manure or organic fertilizer being produced as by-product (Odeyemi, 1979). The technology of biogas production is a method of converting solid wastes into beneficial product by subjecting them to anaerobic bacteria digestion to produce combustible biogas and organic fertilizer. Biogas is mainly composed of $55-75 \%$ methane, $30-40 \%$ Carbon dioxide and trace gases such as hydrogen, carbon monoxide, nitrogen, oxygen, and hydrogen sulphide. 
Biogas is about $20 \%$ lighter than air and has an ignition temperature in the range of $650^{\circ} \mathrm{C}-750^{\circ} \mathrm{C}$. It is an odourless and colourless gas that burns with clear blue flame similar to that of Liquefied Petroleum Gas, its energy value is $20 \mathrm{MJ} / \mathrm{m}$ (Odeyemi, 1979) and burns with $60 \%$ efficiency in a conventional biogas stove (Arotupin, 1999). In addition to animal and human wastes, plants materials can also be used to produce biogas and biomanure. Substrates for biomethanation can be obtained from energy crops apart from municipal solid wastes, household wastes, night soil and industrial waste. Rapidly growing and high yielding plants can be cultured as a means of converting solar energy into chemical energy especially in regions with high sunlight intensity. The study was carried out to seek for a way of reducing solid waste in our environment and to boost the production of biogas. The objectives of this study are to determine the $\mathrm{pH}$, temperature, microbial load and, the composition of the biogas produced from pig dung supplemented with selected crop wastes.

\section{MATERIALS AND METHODS}

\section{Materials}

The materials and equipment used for this study include: Bean husks, Cassava peels, Plantain peels, Yam peels, Pig dung, Weighing balance, Distilled water, Fabricated Anaerobic Digester, Nutrient Agar, Potato Dextrose Agar, Autoclave, Incubator, Petridishes, Gas Chromatography, $\mathrm{pH}$ meter, Thermometer, MacCartney bottles and Microscope.

\section{Methods}

\section{Collection of organic wastes}

The organic wastes used in the biogas production include bean husks, cassava peels, plantain peels, yam peels and piggery dung. The pig dung was collected from a private farm in Ibadan, Nigeria. Yam peels were collected from local restaurants in Ibadan city. Cassava peels were collected from a major cassava processing centre located at old Ife road in Ibadan. The cassava peels consisted of small chopped cassava tuber and stalk. Bean husks were collected from a bean cake seller and the plantain peels were collected at a domestic waste refuse dump.

\section{Preparation of Slurry}

A fresh pig dung of $16 \mathrm{~kg}$ was weighed using a weighing balance, while $1 \mathrm{~kg}$ of yam peels; $1 \mathrm{~kg}$ of cassava peels; $1 \mathrm{~kg}$ of plantain peels and $1 \mathrm{~kg}$ of bean husks were also weighed. Twenty litres of sterile distilled water was used for the mixing which was carried out in a ratio $1: 1(20 \mathrm{~kg}$ of solid wastes: 20 litres of sterile distilled water) to form a slurry. A sterilized rod was used for mixing of the slurry, which was then fed into the digester.

\section{Anaerobic digester}

Digester is a physical structure, commonly known as biogas plant or anaerobic digester. The main function of this structured plant is to provide internal anaerobic conditions, since various chemical and microbiological reactions take place in it. It is used to produce and recover methane gas from the decomposition of manure. Digester used in this study was dome-shaped, constructed with metal. The essential parts of the biodigester were inlet orifice, inlet, fermentation chamber, gas holder, control tap, connecting pipes and outlet as shown in figure 1. The fermentation chamber has volume of 100 litres and height of $1.4 \mathrm{~m}$. The biogas produced was measured by liquid displacement method (Raju and Ramalinghaih, 1997).

\section{Microbiological analysis}

The media used were Nutrient Agar (NA) and Potato dextrose Agar (PDA) and prepared according to the manufacturer's directives. Chloramphenicol capsule was added to molten PDA in order to suppress bacterial growth. Serial dilutions were carried out on the digested slurry using standard laboratory method. Using sterilized petridishes, $25 \mathrm{ml}$ of the sterile molten NA was poured in it and $0.1 \mathrm{ml}$ of the solution $10^{-9}$ dilution was introduced into petridishes. The petridishes were rotated for proper mixing, inverted and incubated at $37^{\circ} \mathrm{C}$ for 24 hours. The same procedure was repeated for PDA using $10^{-5}$ dilution and incubated at $25 \pm 2{ }^{\circ} \mathrm{C}$ for 72 hours with the plates inverted. After the incubation, colonies were counted so as to determine the microbial load.

The bacterial and fungal isolates were purified, characterized and identified using modified standard methods (Arotupin, 1999; Cowan and steel, 1993; Ogundana, 1989; Fawole and Oso, 1995; Atlas, 1984). During the anaerobic digestion, $\mathrm{pH}$ and temperature were taken at 3 days intervals and recorded.

\section{Determination of gases}

This was carried out with the help of gas chromatography. Gas chromatography of HP6890 model was used. The column used was Haysep Q (80/100 mesh) with a length of $10 \mathrm{ft} . x$ 1/8inch having detector temperature of $150^{\circ} \mathrm{C}$. The detector was thermal conductivity detector (TCD). The carrier gas (mobile phase) was nitrogen with $25 \mathrm{psi}$. The chromatographic result is as shown in Figure 1. 




Figure 1. Schematic picture of anaerobic digester.

\section{RESULTS}

The results of the study are as shown in Tables $1,2,3,4$ and Figure 2.

\section{DISCUSSION}

The mixture of pig dung and selected crop wastes fed into digester resulting from microbial decomposition under anaerobic condition produced biogas. Under strictly anaerobic conditions, solid wastes can be digested by microorganisms to generate combustible gas $\left(\mathrm{CH}_{4}\right)$ and Carbon-dioxide with manure or organic fertilizer being produced as by-product (Odeyemi, 1979). As also common with landfills, the products of anaerobic microbial metabolism include carbon-dioxide, water, methane, various low molecular weight alcohol and acids which diffuse into the surrounding water and air causing the landfill to settle slowly (Atlas, 1984).

Viable bacteria count obtained from the waste organic matter i.e. mixture of pig dung with crop wastes before and during digestion with $3.5 \times 10$ (Lund et al., 1996) dilution factor was noticed to be of highest value in the second week when compared with the first and third week. The bacteria count increased at various stages and the microbial load was highest at the second week and consequently decreased as the digestion period increases as shown in the table 1.

The relatively high count in the second week could be traced to factors such as air tight environment, optimum temperature and $\mathrm{pH}$, and various reactions and interactions that would have occurred among methanogens, non-methanogen and substrates fed into the digester as input.
The fungal count was not as much as bacterial count which can be traced to the relative high content of the digested mixture of crop waste and pig dung which favours the development of bacteria rather than fungal population (Atlas, 1984). The fungal count was observed to be decreasing from the first day of digestion from $1.4 \mathrm{x}$ $10^{7} \mathrm{sfu} / \mathrm{ml}$ to $0.8 \times 10^{7} \mathrm{sfu} / \mathrm{ml}$ of the last day of digestion. Yeast count followed the same pattern of decrease as its cell died during the digestion. The decrease might be attributed to inability of the moulds to grow at elevated temperature and utilization of fermentable products of the substrate.

The $\mathrm{pH}$ of digestion obtained at 3 days interval was found to range from 5.2 to 7.1. During the first week, the $\mathrm{pH}$ value increases from 5.2 to 5.4 and then reduces to 5.3 and 5.2 at the seventh and tenth day respectively. The $\mathrm{pH}$ value obtained at this range may be due to the production of large amount of organic acids produced by acid forming bacteria. Acetate and fatty acid produced during digestion tend to lower the $\mathrm{pH}$ of the digester liquor (Marchiam, 1986). Third week has the highest $\mathrm{pH}$ value of 7.1 as shown in table 2 which is as a result of influence of retention time. This may also be due to the concentration of $\mathrm{NH}_{3}$ which increases as a result of digestion of Nitrogen which can increase the $\mathrm{pH}$ value.

The temperature of the environment gives the temperature of the digested pig dung-crop wastes in the digester. Methanogens are inactive in extreme high and low temperatures and when ambient temperature is $30^{\circ} \mathrm{C}$ or less, the average temperature within the digester remains about $40^{\circ} \mathrm{C}$ above the ambient temperature (Lund et al., 1996).

The lowest temperature value as shown in table 3 was obtained in the first, third and thirteen days of digestion and the highest temperature was obtained at the eleventh 
122 Int. Res. J. Microbiol.

Table 1. Microbial population of the blended organic wastes at 3-days interval of isolation during the digestion

\begin{tabular}{lccc}
\hline Days & Bacteria (cfu/ml) & Fungi (sfu/ml) & Yeast (sfu/ml) \\
\hline $\mathbf{1}$ & $2.0 \times 10^{11}$ & $1.4 \times 10^{7}$ & $2.4 \times 10^{7}$ \\
$\mathbf{4}$ & $2.2 \times 10^{11}$ & $1.2 \times 10^{7}$ & $1.8 \times 10^{7}$ \\
$\mathbf{7}$ & $3.0 \times 10^{11}$ & $1.2 \times 10^{7}$ & \\
$\mathbf{1 0}$ & $3.5 \times 10^{11}$ & $1.1 \times 10^{7}$ & \\
$\mathbf{1 3}$ & $1.8 \times 10^{11}$ & $1.0 \times 10^{7}$ & \\
$\mathbf{1 6}$ & $1.5 \times 10^{11}$ & $0.8 \times 10^{7}$ & \\
\hline
\end{tabular}

Table 2. $\mathrm{pH}$ and gas yield variation of the digested waste materials at 3days interval of isolation

\begin{tabular}{llc}
\hline Days & $\mathbf{p H}$ & Gas yield $\left(\mathbf{m m H}_{\mathbf{2}} \mathbf{O}\right)$ \\
\hline 1 & 5.2 & 85.5 \\
4 & 5.4 & 170 \\
7 & 5.3 & 255.4 \\
10 & 5.2 & 314.5 \\
13 & 6.1 & 306.5 \\
16 & 7.1 & 294.5 \\
\hline
\end{tabular}

Table 3. Temperature variation of the environment during digestion of the mixture

\begin{tabular}{lcc}
\hline Days & Digester temperature $\left({ }^{\circ} \mathbf{C}\right)$ & Ambient temperature $\left({ }^{\circ} \mathbf{C}\right)$ \\
\hline 1 & 26 & 25 \\
2 & 27 & 25 \\
3 & 26 & 25 \\
4 & 28 & 26 \\
5 & 30 & 26 \\
6 & 28 & 27 \\
7 & 28 & 25 \\
8 & 30 & 25 \\
9 & 28 & 26 \\
10 & 32 & 27 \\
11 & 34 & 28 \\
12 & 28 & 25 \\
13 & 26 & 25 \\
14 & 32 & 27 \\
15 & 30 & 26 \\
16 & 29 & 25 \\
\hline
\end{tabular}

Table 4. Chemical analysis of the pig dung-crop waste biogas

\begin{tabular}{lc}
\hline Gases & \% composition \\
\hline $\mathrm{CH}_{4}$ & 70.55 \\
$\mathrm{NH}_{3}$ & 13.17 \\
$\mathrm{H}_{2} \mathrm{~S}$ & 5.30 \\
$\mathrm{CO}_{2}$ & 4.69 \\
Traces of other gases & 6.29 \\
\hline
\end{tabular}




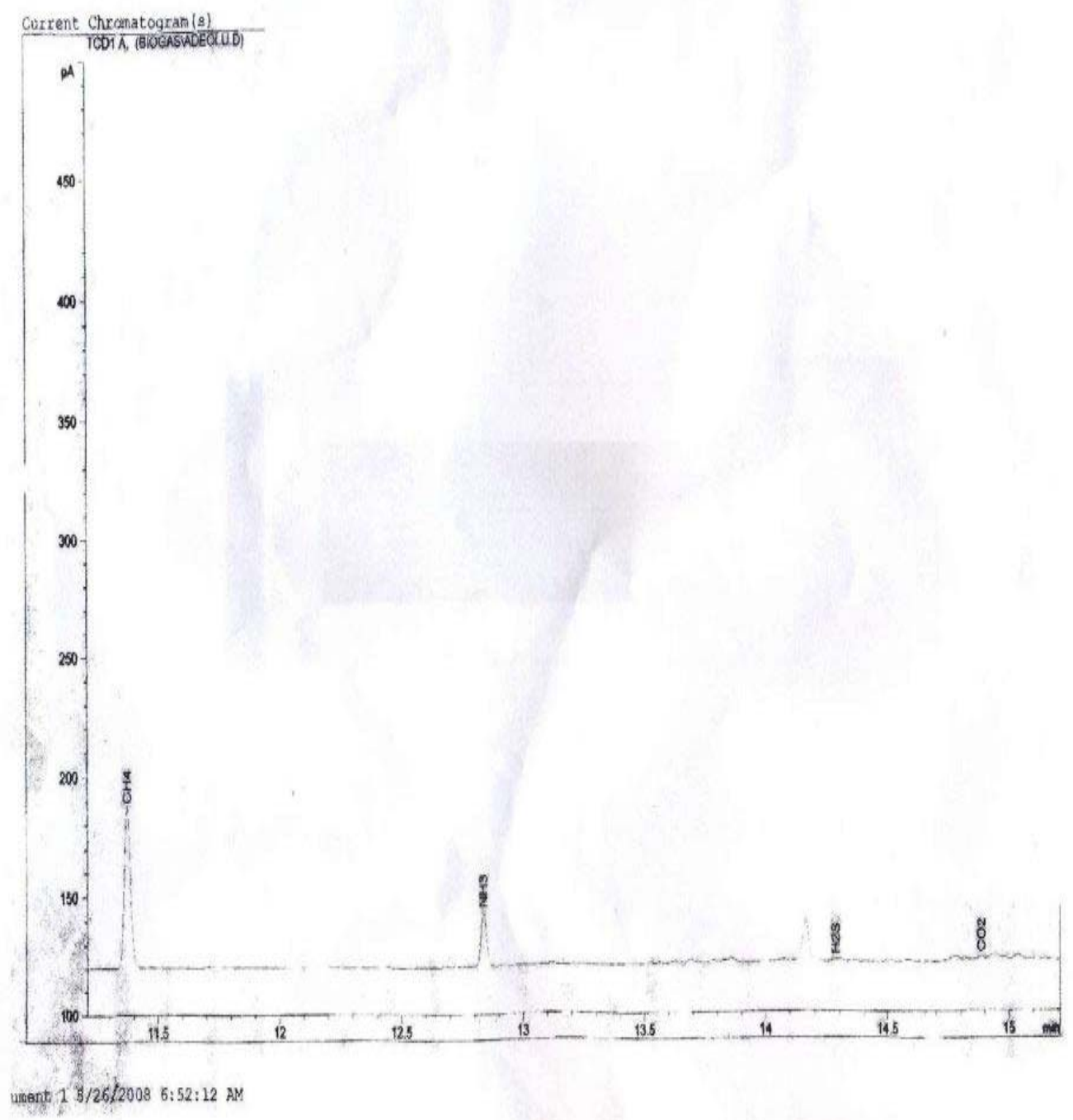

Figure 1. Gas chromatography analysis of the biogas

days, which were $26{ }^{\circ} \mathrm{C}$ and $34{ }^{\circ} \mathrm{C}$ respectively. Since these temperature values remained within the mesophilic range, the growth and activities of methanogens will be enhanced, resulting to the production of biogas. Satisfactory gas production takes place in the mesophilic range. The temperature values obtained within first and second week of digestion enhanced the physiochemical and biological processes of the biomass in the digester.

Figure 1 shows the graph obtained from the gas chromatographic analysis of the biogas produced, the peak represents the highest hydrocarbon gas $\left(\mathrm{CH}_{4}\right)$ followed by ammonia, hydrogen sulphide, carbon IV oxide and traces of other unknown gases, which were found to be low. The peak area of the gas was found to be $190.60619 \rho$ A. The crop wastes added to the pig dung increases the amount of biogas generated especially $\mathrm{CH}_{4}$. This was strictly done to standardise the $\mathrm{C}: \mathrm{N}$ ratio for the anaerobic system. The enrichment process was geared towards system optimization. The variation in $\mathrm{pH}$ and temperature values of crop wastes and pig dung in 
the digester affects the microbial population. It was observed that the quantity of the pig and mixture of the selected crop wastes fed into the digester had a significant effect $(P<0.05)$ on the gas generated by prolonging its production. Also, $85.5 \mathrm{mmH}_{2} \mathrm{O} /$ day was generated compared to $56.9 \mathrm{mmH}_{2} \mathrm{O} /$ day generated by pig dung alone Muyiiya and Kasisira, 2009 and maximum yield recorded at $314 \mathrm{mmH}_{2} \mathrm{O}$ compared to $306 \mathrm{mmH}_{2} \mathrm{O}$ using pig dung alone Odeyemi and Adewumi, 1982. This is an indication that the enrichment materials contributed to the estimated relatively higher yield of the biogas.

This process offered value to solid waste management by reducing wastes from the environment. Biogas provides gaseous fuel for cooking, lighting and heating. This practice will no doubt reduce the wood gathering and fire tending chores of women. In addition, it will also contribute to reduction in the incidences of lung and eye damage resulting from repeated exposure to the smoke of open fires. This practice will also lend support to the control of deforestation. The post digestion sludge is a high quality fertilizer and a soil conditioner which can markedly improve the physical and chemical properties of soil, thereby enhancing its productivity. It improves the environment in lifting health standard through the killing effects of anaerobic fermentation on eggs of parasites and pathogenic enterobacteria from the pig dung. During the digestion process, pathogenic bacteria in the manure were killed, which indicate the safety of its use. This technology if adopted can be used to generate employment opportunity for the growing unemployed youths in developing countries like Nigeria. However, further study should be carried out using mixture of other crops and animal wastes through feeding of these heterogeneous mixtures into the digester to provide biogas and organic fertilizer to improve crops production.

\section{REFERENCES}

LBS (2002). GM Well-to-Wheel analysis of energy use and greenhouse gas emissions of advanced fuel/vehicle systems - A European Study. 133 p., L-B-System technik GmbH, Ottobrunn Germany.

Amon T, Hackl E, Jeremic D, Amon B, Boxberger J (2001). Biogas production from animal wastes, energy plants and organic wastes. In: van Velsen, A.F. M. \& Verstraete, W. H. (eds), Proc. 9th World Congress on Anaerobic Digestion: 381-386.

Odeyemi O (1979). Microorganisms as tools in Bio-conversion of solar energy into Fuel and Fertilizer.Towards a Comprehensive Energy Policy for Nigeria. E.N.C Osakwe (Ed). National Policy Development Centre, Lagos, pp 425-429

Sathianayhan MA (1975). 'Biogas Achievement and Challenges' Association of Voluntary Agencies of Rural Development, New Delhi, India.

Arotupin D (1999). Microbiology: An Introductory Approach, first edition, pp 109-110

Cowan and steel (1993). Identification of Medical bacteria, third edition, Cambridge University Press, pp 50-62

Ogundana SK (1989). Introductory Microbiology. A Laboratory manual. Obafemi Awolowo University Press, lle-Ife, pp 35-69

Fawole MO, Oso BA (1995). Laboratory Manual of Microbiology, Spectrum Books Limited, Ibadan, pp 9-19

Atlas RM (1984). Fundamental Approach to Microbiology, fourth edition, New York, pp 145-290

Marchiam CG (1986). Principle and practices for biogas systems. World Bank Technical paper. No 49.

Lund MS, Andersen SS, Torrry-Smith M (1996). 'Building of a flexibility Biogas Digester in Tanzania' Student Report, Technical University of Denmark, Copenhagen.

Muyiiya ND, Kasisira LL (2009). Assessment of the Effect of Mixing Pig and Cow Dung on Biogas Yield". Agricultural Engineering International: Vol. XI.

Raju K, Ramalinghaih S (1997) 'Methane production from orange waste. Indian Journal of Environmental health, 30, 20-22

Odeyemi O, Adewumi AA (1982). Relative Biogas generation from five animal manures in Nigeria. In: Energex 82. F.A Curtis (ed) vol. 1, pp 285-287. 